University of Nebraska - Lincoln

DigitalCommons@University of Nebraska - Lincoln

University of Nebraska Press -- Sample Books

and Chapters

University of Nebraska Press

Spring 2010

Kansas Politics and Government

H. Edward Flentje

Joseph A. Aistrup

Follow this and additional works at: https://digitalcommons.unl.edu/unpresssamples

Part of the Arts and Humanities Commons

Flentje, H. Edward and Aistrup, Joseph A., "Kansas Politics and Government" (2010). University of Nebraska Press -- Sample Books and Chapters. 99.

https://digitalcommons.unl.edu/unpresssamples/99

This Article is brought to you for free and open access by the University of Nebraska Press at DigitalCommons@University of Nebraska - Lincoln. It has been accepted for inclusion in University of Nebraska Press -- Sample Books and Chapters by an authorized administrator of DigitalCommons@University of Nebraska - Lincoln. 
KANSAS POLITICS AND GOVERNMENT 


\section{Politics and Governments}

of the American States

Founding Editor

Daniel J. Elazar

Published by the University of Nebraska Press in association with the Center for the Study of Federalism at the Robert B. and Helen S. Meyner Center for the Study of State and Local

Government, Lafayette College 


\section{Kansas}

Politics and

Government

THE CLASH OF POLITICAL CULTURES 
(C) 2010 by the Board of Regents

of the University of Nebraska

All rights reserved

Manufactured in the United States

of America

(0)

Library of Congress Cataloging-in-

Publication Data

Flentje, H. Edward.

Kansas politics and government: the clash of political cultures / H. Edward Flentje and Joseph A. Aistrup.

p. cm. - (Politics and governments of the American states)

"Published by the University of Nebraska Press in association with the Center for the Study of Federalism at the Robert B. and Helen S.

Meyner Center for the Study of State and Local Government, Lafayette College."

Includes bibliographical references and index. ISBN 978-0-8032-2028-7 (cloth: alk. paper) ISBN 978-0-8032-69I9-4 (pbk.: alk. paper)

I. Kansas-Politics and government.

2. Political culture-Kansas. I. Aistrup,

Joseph A., I960- II. Title.

JK68I6.F57 2010

$320.478 \mathrm{I}$ - dc22

2009026565 
Introduction, xi

ONE

Political Cultures, I

TWO

The Constitution, 30

THREE

Elections and Political Parties, 50

FOUR

The State Legislature, 73

FIVE

The Governor, Ioo

SIX

Interest Groups and Lobbying, I30

SEVEN

State and Local Governments in a Federal Structure, I 50

EIGHT

Taxing, Spending, and Borrowing, I70

NINE

Kansas Politics in State and Nation, I93

APPENDIXES

I. The Kansas Court System, 20I

2. Summary of Legislation Governing Lobbying in Kansas, 202

Notes, 207

Suggestions for Further Reading, 239

Index, 245 
I. Classification of Counties, $\mathrm{xx}$

2. Political Cultures, 3

3. Cultural Alliances of National Political Parties, 22

4. Cultural Placement of Historic Political Forces in Kansas, 23

5. Cultural Alliances of Kansas Republican Factions, 25

6. Voter Registration by Party Identification, I974-2006, 56

7. Percentage of Democrats in the State Legislature, I927-2007, 56

8. Percentage of Republican Votes for

President and Governor, I956-2006, 57

9. Post-Civil War / Progressive Party Alignment, 6I

Io. New Deal Party Alignment, 64

I I. New Right Party Alignment, 65

I 2. Percentage of Republican Two-Party Registration in Sedgwick County, 66

I3. State Government Organization Chart, I Io 
I. Constitutional Revisions Adopted in I972 and I974, 38

2. Constitutional Revisions Adopted between I976 and I988, 39

3. Model State Constitution and Kansas Constitution, 46 4. Rights and Restrictions in Other States and Kansas (2005), 47

5. Constitutional Provisions in Other States and Kansas (2005), 48

6. Election Defeats of Republican Candidates for Governor, I 859-2006, 52-53

7. Gubernatorial, U.S. Senator, and Presidential Winners in Kansas, I9I2-2006, 58-59

8. Regression Analyses of Republican Normal Vote for Governor on Selected Demographic Characteristics, by Major Party Alignment, 62

9. Classification of Professional and Amateur Legislatures in the U.S., 74

Io. Average Job Time, Compensation, and Staff Size by Category of Legislature, 75

I I. Occupations of Kansas Legislators, I977 and 2007, 79

I 2. Primary Challenges to Republican Incumbents, I990-2006, 92 I3. House Speakers and Senate Presidents, I993-2007, 94 I4. Number and Percentage of Partisan News Stories in Wichita Eagle, 96 I 5. Partisan Stories in Wichita Eagle, for Selected Years, I988-2005, 97 I6. Kansas Governors, I859-2008, I $02-$ I 03 
I7. Election Victories in Kansas Gubernatorial Contests, by Party, I86I-2006, I05

I8. Gubernatorial Vetoes and Veto Overrides, by Governor, I967 to present, I I 4

I9. Executive Reorganization Orders, Proposed and Disapproved, by Governor, I974-2008, I I 8

20. Number of Registrations and Number of Lobbyists, I977-2006, I35

2 I. Growth of Lobbying and Contract Lobbying in Kansas, I967-2006, I 37

22. Number of Registered Interests and Registered Lobbyists, by Type of Interest Group, I986 and 2006, I38-I39

23. Comparison of Backgrounds of Contract and Association Lobbyists, I43

24. Percentage of Women Lobbyists and Contract Lobbyists, I44 25. Comparison of Attitudes and Opinions of Contract and Association Lobbyists, I 46 


\section{Acknowledgments}

The rich history of Kansas politics continues to spawn an abundant literature on the subject. Our state's beginning as Bleeding Kansas followed by prohibition, populism, the progressive era, a national depression, and the Dust Bowl has given local and national scribes, as well as scholars, an intriguing topic for conversation and serious study. More recent developments in state affairs involving national intervention, evangelical movements, and taxpayer discontent, among others, have drawn similar attention. Historians and biographers have shed light on pieces of this history, just as journalists help in understanding various slices of current political affairs in the state. Rarely, however, are past and present connected in order to fully illuminate our understanding of Kansas politics and government.

This volume uses the prism of political cultures in order to interpret Kansas politics and to show the intimate connections of the state's past with its current politics. The framework of political cultures evolves from underlying political preferences for liberty, order, and equality, and these preferences form the basis for the active political cultures of individualism, hierarchy, and egalitarianism. This volume makes the case that Kansas politics, historically and currently, may best be understood as the clash of these political cultures.

The chapters that follow bring together for the first time in one volume a comprehensive examination of Kansas politics. This volume addresses the state's primary political institutions - the constitution and courts, the legislature, and the governorship. It also explores the vehicles of political process - party politics, elections, and interest groups, in addition to the influence of political cultures on institutions and process. Further, it examines within the framework of political cultures the impact of federalism on state politics and government, and finally, it covers the politics of state financetaxing, spending, and borrowing. 
This volume is addressed to anyone, both casual observers and serious scholars, with an interest in Kansas state politics or in state politics in general. This audience would include any citizen of the state, elected and appointed officials in Kansas governments, students and teachers of Kansas politics and government, journalists, and academics.

The authors wish to acknowledge the support received in preparation of this volume from their respective universities, Wichita State University and Kansas State University, and thank university officers for their encouragement on the project. In addition, a special thanks goes to staff members of the Hugo Wall School of Urban and Public Affairs at Wichita State, specifically to Graduate Assistants Michelle Ponce and Deanna Carrithers for research and editorial assistance and to Associate Director Jo Turner for bringing the manuscript into final form. Further, David Warren provided editing assistance on various versions of several chapters.

Special thanks goes to Jeremy Stohs, who at Kansas State University wrote a fine senior thesis on the growth of professional lobbyists in Kansas. $\mathrm{He}$ is a coauthor of chapter 6 that focuses on interest groups. We also wish to thank Mark Bannister at Fort Hays State University, who conducted a large number of interviews with party operatives in Kansas. His interviews were used in chapter 3 to analyze the historical development of state party organizations in Kansas.

Through personal interviews and through access to numerous official documents, many current and former state officials assisted in this endeavor. The authors particularly wish to thank the staff of the Kansas Legislative Research Department and the Kansas Division of the Budget for assistance in this regard. 


\section{Introduction}

Few news stories in recent memory have come to symbolize Kansas politics in the twenty-first century more than the controversy over the inclusion of Darwin's theory of evolution in the science standards for Kansas public schools. This saga was not Kansas' first brush with the issue, but it is the state's most memorable one. ${ }^{1}$ In I999 six Republicans on the Kansas State Board of Education voted to eliminate references to "macroevolution" and the "big bang" theory from the state's science standards. Their decision set off a firestorm of criticism both inside and outside Kansas. National science groups refused to grant the board its copyrighted materials. Republican Governor William Graves ridiculed the decision as "terrible and tragic." Late night TV comedians quipped that Kansas had become "Y IK compliant."2 For its part the board's majority noted that its decision did not preclude any local school board in Kansas from allowing its science teachers to teach macroevolution or the big bang theory but that state assessment tests for science would not include questions on these topics.

The board's vote mobilized a slate of self-proclaimed moderate Republican candidates to challenge four of the six antievolution Republicans who stood for reelection in the 2000 GOP primaries. Three moderate Republicans won both the primary and the general election. ${ }^{3}$ Upon taking office in 200I, the new board's first order of business was to reinstate the old science standards that included discussion of evolution and the big bang theory. This story would have ended in most states but not in Kansas.

In the wake of the 2000 Republican primary Kris Van Meteren, the executive director of the Kansas Republican Assembly, which is a voice for the evangelical wing of the Kansas GOP, stated, "Next time, when all the liberals are up, you can rest assured we'll be going after them." 4 Van Meteren made good on his promise. In the 2002 GOP primary two Republicans en- 
dorsed by the Kansas Republican Assembly defeated proevolution Republican incumbents; the result was a board evenly split on the evolution issue. ${ }^{5}$ The tie would be broken after the 2004 Republican primary when Kathy Martin, endorsed by the Kansas Republican Assembly, defeated incumbent Republican Bruce Wyatt.

In 2005, with antievolution Republicans restored to majority status, the board again initiated a review of the state's science standards. The hearings to adopt the new standards approached a circus atmosphere as attorney Pedro Irigonegaray targeted the majority's expert witnesses with heavy sarcasm. Political theatrics aside, the board majority approached the issue with more subtlety in 2005 than in I999. The definition of science was revised to allow for natural and "unnatural" explanations of natural phenomena and to permit criticisms of evolutionary theory. Although never mentioned in the new standards, the subtext of the new tactic was to give local school boards and science instructors the option of teaching intelligent design in addition to evolutionary theory. ${ }^{6}$ After 2000 intelligent design had gained widespread popularity among religious groups opposed to the teaching of evolution. These groups felt intelligent design provided a more scientific justification for their belief that life is too complex to be explained by random chance and that consequently a God is responsible for tailoring the universe and creating life in his image.

History has a way of repeating itself in Kansas, sometimes again and again. In shades of the 2000 GOP primary a slate of four moderate Republican candidates challenged three incumbent board members, all of whom had voted to revise the science standards, and contested an open seat vacated by another member who had voted for the revisions. Proevolution candidates won two of these seats, thus regaining the majority. In January 2007 the first order of business was repealing the handiwork of the old board and reinstating the prior science standards.

Some may argue that this ongoing political conflict represents a side show that is not reflective of Kansas politics. This view, however, fails to recognize that political conflicts like the scrap over evolution reveal the cleavages among the dominant political cultures that have shaped state politics and government from the moment the Kansas Territory opened for settlement in the I850s. These competing cultures have fundamentally different visions of the role of government in enforcing moral order, encouraging individual liberty, and pursuing equality. Thus these competing visions provide both the spark and the fuel for political flames that often burn brightly for years and are visible throughout the country. One does not need to look far into Kansas history to find other political fires that exceed both the intensity and national significance of the evolution debate. 
The first of these political infernos started raging with the birth of Kansas, which is synonymous with one of the darkest segments of U.S. history, the Civil War. The earliest battles of the Civil War were fought in the Kansas Territory between supporters of slavery, most of whom migrated from neighboring Missouri, and free-soil immigrants from a variety of midwestern and northeastern states. Unlike any other state, the settlement and formation of Kansas was a battleground over competing visions of moral order regarding the issue of slavery. Not long after abolitionists had won this battle, they started to promote the use of government power to enforce their vision of a good society on other issues unrelated to slavery.

Even though abolitionists dominate the early history of the state, most who settled Kansas also brought values associated with Jacksonian democracy. Of the Jacksonian mix of individualism and equality, the former found fertile soil and set deep roots in Kansas politics. Kansans embraced individual liberty with a constitution that placed strict restraints on state government and accordingly encouraged grassroots democracy and economic freedom to blossom outside the confines of state government. Kansans' passion for liberty made Kansas the boom state of the post-Civil War period. Within the first thirty years of statehood nearly two million people immigrated into Kansas; entrepreneurial towns sprung up across the state; nine thousand miles of railroads were built; and fifty million acres of Kansas soil moved from public domain into private hands.

Jacksonian democracy produced lively and often chaotic politics in Kansas. Diverse streams of immigration also brought contrasting political views into the state. ${ }^{7}$ Even so, in the aftermath of the Civil War most immigrants embraced the party of Lincoln, which quickly rose to dominance. Though often fragmented, Republican Party politics, along with predominant economic interests_-primarily railroads_ruled state politics into the twentieth century. Politics and business intermixed, and political deal making permeated Kansas politics for most of the state's early history.

Jacksonian Democrats and Gilded Age Republicans could heartily agree upon the ideal of limited government and a diffusion of political power. Strict limits on the taxing, spending, and borrowing authority of state government were written into the state constitution. Restraints on the legislative institution assured that citizen volunteers rather than career politicians would be in charge of legislating. Executive power was restrained and diffused among the governor and six additional executives elected statewide. Local control thrived. Kansans would spend most of the twentieth century working to loosen the legal shackles cuffed on state government in the last half of the nineteenth century. 
Another strain in Kansas political life emerged from the battle to make Kansas a free state in the I850s. Amid the disorder of rampant individualism, the abolitionists' message of a good and orderly society found a willing audience among the flood of immigrants aligned with evangelical Protestant denominations. These societal reformers coalesced into a countervailing force in the politics of the day and eventually resorted to the coercive powers of state government to achieve their vision of a good society. They embraced, for example, the prohibitory movement-writing a prohibition on the sale of intoxicating liquors into the state constitution as early as I880 - and moved with vengeance to enforce the ban, thus embroiling Kansans in a century-long struggle over regulating intoxicating liquors. Republican partisans embraced this evangelical movement and established themselves as the party of prohibition. So early in the political life of the state, the Kansas Republican Party placed itself on seemingly contradictory footings as it championed on the one hand economic liberty-free markets and restraints on government - and on the other moral order-prohibition and various other measures designed to establish standards of community conduct through the force of law.

Kansas also experienced a unique egalitarian moment in the I890s. Hammered by national policies protecting creditors and the railroads as well as by drought, farmers rebelled and demanded an end to the inequities brought on by the politics of individualism. These populists championed a national agenda of graduated taxation, public ownership of railroads, government loans, and confiscatory land reform. Over four election cycles, I 890 through I 896, they undermined Republican hegemony, electing two governors and a U.S. senator and winning a majority of contested seats in the U.S. House and the Kansas legislature. After winning control of most state offices in I892, the populists became embroiled in internecine warfare, and their surge stalled. Their inherent distrust of authority, even that exercised by their own officeholders, subverted their ability to govern. The Populist Party departed from the scene shortly thereafter but sowed a passion for equality into Kansas political soil that lives to the present day.

In part motivated by the rise of the populists, after the turn of the twentieth century the Republican Party dislodged itself from the railroad interests that had dominated state politics for decades and moved toward an emerging business and professional constituency, becoming progressives dedicated to both political and moral reform. Progressive era Republicans remained devoted to a moral agenda of enforcing prohibition, outlawing abortion, banning cigarettes, and forbidding evil in various other forms.

More important, the progressives unleashed an array of political and eco- 
nomic reforms aimed at reforming state politics, regulating the economy, and broadening the authority and scope of state government. Political reforms-primary elections, recall procedures, suffrage for women, and direct election of U.S. senators, among other measures designed to make state politics more accessible to ordinary citizens-were authorized. Economic regulation of workplace conditions, fraudulent securities, public utilities, food and drugs, and child labor laws were instituted. Newly created state offices, expansions in higher education, and broader state authority in environmental protection and public health, among many other enactments, augmented the scope of state government.

All of the reform movements-abolition, prohibition, populism, and progressivism - did give Kansas a distinct political heritage and placed the state in the forefront of national political change. Early in the twentieth century William Allen White, the worldly editor of the Emporia Gazette, opined that "when anything is going to happen in this country, it happens first in Kansas." 8 The upcoming decades, however, would temper these passions and reshape state politics and government in fundamental ways.

For starters the I930s were not kind to Kansas. On top of a national depression, a good part of the state was smothered by the Dust Bowl-an extended period of drought, withering heat, terrible winds, and air thick with blowing dust. Grain prices plummeted. Rural Kansas lost one hundred thousand people, one-seventh of its population, between I930 and I940. Kansas' infamous goat-gland doctor, John Brinkley, appealed to those in distress and nearly won the governorship_-by write-in ballot no less. Unable to escape their political past, Kansans reverted to belt tightening on state government as a solution, and in desperation both fiercely independent farmers and state leaders turned to the national government for help. National assistance was forthcoming, and at least for a time many joined FDR's New Deal and cast their votes in the Democratic column.

Grudging acceptance of agricultural assistance was followed quickly by Kansans' overwhelming endorsement of national income security. Kansas voters willingly adjusted their constitution to allow state government and its local jurisdictions to abandon past restraints and participate in income support and welfare assistance administered nationally through the Social Security Act of I935. Shortly thereafter World War II deepened further the penetration of national administration in Kansas. Existing military bases expanded, and new ones sprung up as the state willingly enlisted to aid in national defense. Within two short decades public policies in agriculture, income security, and defense were dramatically broadened to serve national purposes, and policy change coupled with national administration 
of these arenas would have profound and lasting effects on state government and politics.

Kansas historians point to the monumental defeat of Governor Alf Landon in the presidential contest of I936 as a critical turning point in the political consciousness of Kansans. ${ }^{9}$ Kansas voters rejected their native son in favor of FDR, as did their counterparts in every state in the Union except for Maine and Vermont. Kansans began to wonder if their long-standing political passions were out of sync with the nation. Instead of cutting edge had Kansas become a political backwater?

The three decades of the postwar period accelerated the trends of the I930s and I940s in terms of nationalizing influences. The election of Kansan Dwight Eisenhower to the presidency restored a measure of home-state pride, but Eisenhower was a product of national and international experiences, not state politics. More important, the I960s and I970s spawned a flood of national initiatives on everything from preventing juvenile delinquency to controlling rats. By I980 over five hundred grant-in-aid programs were on the books, compared to a dozen in I950. Funding for these programs jumped forty-fold between I950 and I985. The availability of easy money from Washington diverted the attention of state and local officials to purposes outlined by Congress and specified across a raft of national agencies. By I980 dollars from the U.S. treasury comprised nearly one-third of all revenues of state and local governments. Kansas officials chased after the easy money like their counterparts in other states.

The depression, the Dust Bowl, and the nationalizing impacts of income security and defense, among other influences, throttled political passions in Kansas, at least for a time. By 1983 Washington Post columnist Neal Peirce and coauthor Jerry Hagstrom in a book on the fifty states labeled Kansas the Eclipsed State. ${ }^{10}$ Responding to White's statements in the I920s, the authors concluded that Kansas "is scarcely the place where things happen 'first.' Indeed, nowhere on the continent can the eclipse of a region or a state as a vital force - $\mathrm{a}$ focal point of creative change or exemplar of national lifebe felt so strongly and poignantly as in Kansas." 11

Kansas may have moved out of the national political limelight, but it did not lose its zest for reform. In the I950s and I960s political leaders, socialized during the progressive era, began to follow a more active path, turning their attention to revitalizing state and local government by bringing the state's constitution up to date. Forty-three constitutional amendments were adopted by voters from I957 through I986. The political institutions of state government were transformed by unifying the judicial branch, consolidating executive powers, loosening restraints on legislative prerogatives, 
modernizing taxing authority, lifting limits on spending, allowing home rule for cities, and repealing the century-old provisions prohibiting liquor and gambling.

The constitutional reforms and the politics that followed set the stage for the modern era of state politics and government in Kansas. Augmented powers reenergized the political institutions of state government, and state policy makers began exercising new initiatives in public policy. The election of Ronald Reagan accelerated this trend by restraining Washington's domestic spending through substantial tax cuts and increased spending on national defense; it was a trend that would extend into the early years of the twenty-first century.

Leading the resurgence in state politics and government were activist governors, state courts, and legislative leaders. The governorship has become the prime source of political leadership in Kansas. Despite the state's domination by the Republicans, enterprising Democrats have been at the forefront of constitutional revisions; of decisions concerning taxing, spending, and borrowing; and of the restructuring of state government. In the early I970s Democratic Governor Robert Docking in cooperation with legislative leaders promoted sweeping structural reforms through revisions to the state's constitution. In the early I980s Democratic Governor John Carlin championed an ambitious expansion of the scope of state government in spurring economic growth through constitutional amendments and newly empowered agencies funded by a newly authorized state-sponsored lottery. Republican Governor Mike Hayden followed in the late I980s with initiatives in highway and environmental finance and fundamental reform of the state income tax. In the early I990s Democratic Governor Joan Finney under pressure from state courts worked with legislative leaders to raise state taxes, to shift school finance away from reliance on property taxes, and to substantially equalize funding between rich and poor, urban and rural school districts. In the early 2000s Democratic Governor Kathleen Sebelius successfully navigated state finances through the aftermath of 9/I I, and again prompted by the intervention of state courts, she assembled a bipartisan coalition of moderate legislators to increase school aid by $\$ 750$ million over a four-year period. These actions over the past fifty years took shape through a healthy competition of ideas that were attributable in large measure to a renewed vitality of the state's political institutions.

The resurgence in the political institutions of state government has taken place within a shifting political environment. Evangelical Protestants and orthodox Catholics, both groups energized by abortion politics in the I970s and nurtured by Ronald Reagan in the I 980 s, have become a powerful force 
in Kansas Republican politics. These newcomers to state politics first focused on abortion but eventually shifted their attention to evolution, gambling, gay marriage, stem cell research, and other issues they believe to be critical in restoring a good society. They began with protests in the I970s and I980s in front of Planned Parenthood offices across the state, coalesced their forces to descend on Dr. George Tiller's abortion clinic in Wichita in the summer of I99I, and thereafter focused on gaining political power and have done so with great success. Over a fifteen-year period these partisans have gained control of local and state Republican party organizations, challenged incumbent Republican officeholders who do not share their vision, gained positions of leadership in the state legislature, and taken control of the Kansas State Board of Education for two terms.

These political developments have split the Republican Party into two camps, one championing an aggressive agenda on moral and economic issues and one seeking a more moderate middle ground. With the Republican Party divided, the governorship — the crown jewel of state politics-has escaped the grasp of these newly energized party activists. Republican candidates carrying the activist banner were overwhelmingly defeated in elections for governor in 2002 and 2006 as moderate Republicans abandoned their party's ticket. Indeed, in both elections Governor Sebelius persuaded high-profile moderate Republicans, including a former state party chairman, to desert their party, cross over, and join her on the Democratic ticket as lieutenant governor. Further, in the 2006 contest for attorney general, another crossover to the state Democratic ticket, former Johnson County attorney Paul Morrison, defeated by a landslide a leading protagonist of the activist faction, Republican Attorney General Phill Kline.

The success of the partisans of a moral agenda has been mixed. They did secure a constitutional ban on gay marriage and civil unions in 2005 and through legislative action succeeded in restricting abortion practices at the University of Kansas Medical Center. However, their moves to otherwise limit abortion have largely stalled. They delayed but could not block casino gambling, which was authorized in the 2007 legislative session, while their attempts to ban Darwin from high school biology classrooms have moved to and fro, gaining Kansas national headlines but falling short of eliminating the teaching of evolution from the state's science standards.

The policy advances of those promoting moral order have been limited, this movement has added much fluidity to party politics in Kansas. Republican Party leaders try to patch over the chasm in their party's ranks. Their top nominees lick the wounds of stunning defeats. Despite all this, U.S. Senator Sam Brownback's plans to run for governor in 20 Io provides these parti- 
sans a measure of hope that one of their own will finally be elected governor and that state policies will begin to reflect their values more fully.

The politics of the late twentieth and early twenty-first centuries have ushered in a new era of "it happens first in Kansas." Twenty years after Peirce and Hagstrom's broadside, Thomas Frank contended that Kansas had again become the epicenter for national politics. ${ }^{12}$ His modern and revised book-length version of William Allen White's I896 editorial, "What's the Matter with Kansas?" also took a decidedly negative view of the state's political landscape. Frank concluded that social issues such as abortion, homosexuality, and evolution act as a smoke screen that is used by Republican politicians to align religiously inclined working class voters with the interests of Wall Street.

\section{DEMOGRAPHIC AND ECONOMIC CHANGE}

As this volume will show, the clashes of political cultures explain much of the historic and current dynamics of Kansas politics and government. Within the political environment shaped by such cultures, changing demographic and economic conditions in Kansas also produce opportunities for episodic coalitions that form around urban versus rural interests.

When Kansas was settled in the latter half of the nineteenth century, most of the population made their homes in rural areas and earned a living from farming and ranching. For the entire twentieth century the industrialization of agriculture has led to larger farms and fewer farmers. Exacerbating this trend were events like the Dust Bowl in the I930s and the agricultural downturn of the mid-I980s. As the population of farmers and ranchers has declined, so too have the populations of many rural communities. Counterbalancing the loss of rural people is the growing population in a small number of urban counties and counties immediately adjacent to these urban centers. ${ }^{13}$

These demographic and economic changes have on occasion placed other strains on state politics, creating what many interpret as an urban-rural divide. Those who focus on this characterization of Kansas politics tend to emphasize that two-thirds of the state's one hundred and five counties reached their peak population in 1930 or before and that the population of the state's five urban counties now exceeds that of the other one hundred. Further, they point out that Johnson County in the Kansas City metropolitan area, has a population of five hundred thousand, which equates to that of sixty rural counties in western Kansas.

These statistics, however, fail to recognize the complexity of Kansas' 
$\mathrm{xx}$ Introduction

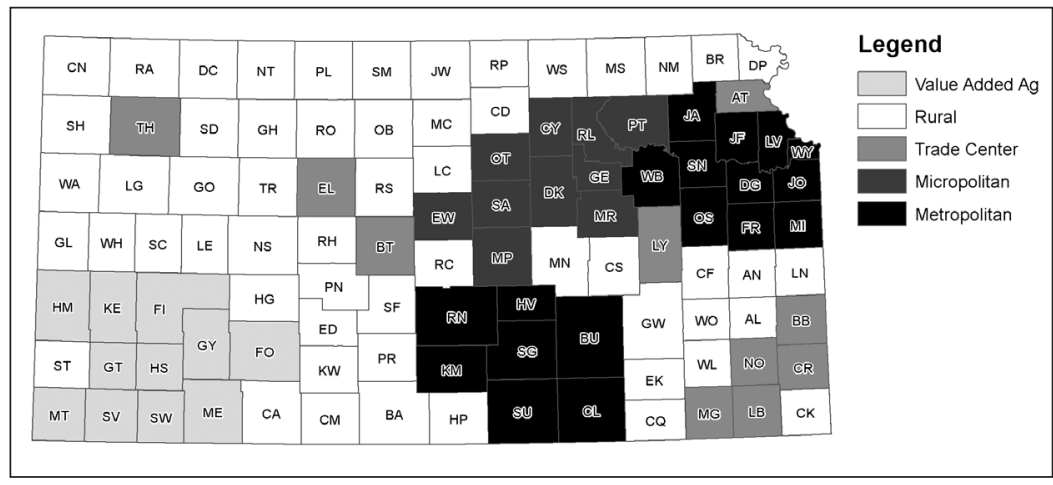

Fig. I. Classification of Counties

Value-added Counties (3): population chg. $65 \%$; per capita income $\$ 25,605$; adjacent value-added rural counties (9); population chg.I I.I\%; per capita income $\$ 28,960$.

Rural Counties (55): per capita income \$27,8 I2; population chg. I9.4\%.

Trade Center Counties (IO): per capita income $\$ 28, \mathrm{I} 8 \mathrm{O}$; av. population chg. $-4.2 \%$. Micropolitan Counties (2): per capita income $\$ 3$ I ,465; population chg. I9.2\%; adjacent rural counties (8); per capita income \$3I,509; population chg. -I.4\%.

Metropolitan Counties (5): per capita income \$40,240; population chg. 48.7\%; adjacent rural counties (I3); per capita income \$30,O I I population chg. $25.4 \%$.

Note: Per capita income data taken from 2006 Census; population change is measured for years I97 I to 2007. Source: Kansas Statistical Abstract, 2008.

demographic and economic characteristics. Figure I captures some of this complexity by viewing Kansas counties from a framework of economic clusters. This perspective emphasizes that growing counties have one or more clusters of economic activity that stimulate employment, raise the standard of living, and boost population in the county and its contiguous areas due to spillover effects. ${ }^{14}$ Counties without such economic clusters or counties that are not close to those with a cluster tend to be losing population.

Kansas counties can be divided into five economic categories drawing upon this framework of economic clusters. ${ }^{15}$ First, the fifty-five mostly smaller rural counties that depend primarily on extractive industries related to farming, ranching, and oil and natural gas are the most economically distressed. In these counties government jobs in public schools and county courthouses have become a major source of employment, and transfer payments such as Social Security have become a primary source of personal income. The per capita income of these counties in 2006 was about \$27,8 I 2, and their population decline for the period I97 I through 2007 was I9.4 percent.

The five largest urban counties (Douglas, Johnson, Shawnee, Sedgwick, and Wyandotte) and the thirteen adjacent rural counties that surround them 
comprise the second category. The per capita income of the five urban counties was $\$ 40,240$ in 2006, and their population growth for the thirty-six-year period was 48.7 percent. In the thirteen counties surrounding the large urban centers, the per capita income was \$30,0 I I, and the population growth was 25.4 percent.

Closely related to these metropolitan counties is a third group, two "micropolitan" counties, Riley and Saline, and their adjacent rural counties. Neither Riley nor Saline qualifies as a metropolitan area, but both are approaching this designation. Their per capita income in 2006 was over \$3I,000, while their population growth over the thirty-six-year period approaches 20 percent. In contrast, the adjacent counties are comparable to the micropolitan counties in personal income, but their population has declined slightly by I.4 percent.

Fourth are counties in the southwestern corner of the state that dramatically dispute the myth that all rural Kansas counties are losing population. In this region three counties, Finney, Ford, and Seward, have economic clusters based on value-added meat processing. On the positive side their population growth between I97I and 2006 was 64.5 percent. However, the work force associated with meat processing tends to be composed of more transient and immigrant laborers. The pay scale of these jobs is typically lower than other industrial classifications, and working conditions are more dangerous. ${ }^{16}$ Thus the per capita income in these three counties was less than $\$ 26$,000 in 2006. The real winners of the value-added agricultural complex in the southwest are the nine adjacent rural counties. Because of the spillover effects counties surrounding Finney, Ford, and Seward had per capita income of $\$ 28,960$ in 2006 , while their population increase between I97I and 2007 was I I.I percent.

Making up a fifth group of Kansas counties are trade centers generally formed around one town with populations between ten and thirty-five thousand and a large employment basis in retail, government, and services. Ten of these counties dot the Kansas landscape, mostly in the central and eastern half of the state. Their per capita income was $\$ 28$, I00 in 2006, but over the past thirty-six years their population declined by 4.2 percent. Their populations have remained stagnant because these counties depend on the smaller rural counties adjacent to them for trade dollars, and as noted above, those counties have fallen on hard times. As the population of counties adjacent to the trade centers declines, so does the economic viability of the trade centers unless they can find another source of external dollars.

While the mix of economic clusters across Kansas tempers urban-rural 
conflicts, important episodes have thrown urban and rural interests into contention. The most divisive are the battles over rectifying the historic malapportionment of the state legislature. In I964 and I966 reapportionment based on one person-one vote forced a dramatic loss in legislative representation for rural Kansas and a redirection of state budgetary resources to address urban issues related to transportation and schools. However, unlike some states where the retribution against rural areas was swift and severe, this effect was less in the case in Kansas as a majority of the state's population at the time still lived outside of the urban centers.

Another major urban-rural battle occurred over public school consolidation. As a reflection of demographic changes noted above, Kansas lawmakers over a twenty-year period consolidated over 5,000 rural school districts into 348 unified school districts. This gut-wrenching affair profoundly diminished hundreds of smaller rural communities and their residents throughout the state, and for these rural residents the word consolidation became, and continues to be, the longest four-letter word in the English language. ${ }^{17}$

Urban and rural interests collided again in the mid-I980s over the issue of liquor by the drink. Governor Carlin assembled an almost purely urban coalition primarily from the Wichita and the Kansas City metropolitan areas to support the constitutional amendment, but after passage, this alliance vanished.

Resource and environmental issues are yet another source of occasional conflict between urban and rural Kansas. In the I980s Governor Carlin proposed and lawmakers passed a severance tax, which urban legislators from the northeast supported and which many rural legislators opposed, particularly those in the oil and natural gas counties of the western half of the state. However, business interests in Wichita, tied closely to the oil and natural gas economy of the state, persuaded many Wichita area legislators to oppose the legislation.

In addition, for the past thirty years there has been an ongoing policy debate regarding the overappropriation of the Ogallala Aquifer for irrigated crops in southwestern and northwestern Kansas. Despite calls by academics and environmentalists to resolve this issue, Democratic and Republican administrations alike have kept the issue contained within the Kansas Department of Agriculture. ${ }^{18}$

Finally, in the 2008 legislative session Governor Sebelius's administration ignited a political storm with rural western Kansas after her secretary of the Kansas Department of Health and Environment denied an air quality permit that prevented Sunflower Electric from building two seven hundred megawatt coal-fired plants near Holcomb in southwestern Kansas. This 
decision aligned the governor with eastern urban interests concerned with carbon emissions and their environmental impact on public health, and it infuriated western Kansas legislators who believed this project would open doors for greater rural economic development, wind farm expansion, and population growth.

Except for malapportionment and liquor by the drink, few of the aforementioned issues have divided Kansas along a strictly urban-rural cleavage. During the 2008 legislative session, for example, Republicans from all parts of the state lined up in favor of passing legislation allowing the coal-fired plants to be built in Holcomb, while mostly Democrats, except for the few from western Kansas, opposed this legislation.

The intermingling of urban and rural interests across the state tend to make political conflicts along these lines episodic in character. In most years this cleavage is more like a semidormant fault line in the earth's crust. Occasionally the fault line sends rumbles through the political landscape, as, for example, when the state welfare agency proposes to consolidate county offices in rural areas. Nonetheless, in an average year this fault line remains largely inactive.

There are signs, however, that pressure along this political fault line will build. Simply put, providing a full range of government services to a widely dispersed, aging population costs dearly and confronts a growing demand by taxpayer groups like Americans for Prosperity to cut taxes and curb the growth in government spending. These pressures to cut government spending may yet ignite a movement to consolidate governmental services in rural communities ranging from schools to courts to public health, to perhaps even county governmental units. Another round of consolidation would trigger a divisive period in Kansas politics that would rival all others. But this day has not yet arrived and is not likely to arrive as long as the dominant Republican Party maintains its bases of support in both rural and suburban areas of the state.

\section{ORGANIZATION OF THE BOOK}

The balance of this volume focuses on explaining the modern era of Kansas politics and government in the context of the state's history and political cultures. In chapter I the passions of state politics are viewed and interpreted through the prism of political cultures. The political cultures associated with Kansans' preferences for liberty, order, and equality are traced over time, and their impact on contemporary state politics is analyzed. This framework of political cultures is then used when appropriate in the remain- 
ing chapters in order to examine in more depth the cultural context of state politics and government with respect to political parties, political institutions, federalism, and fiscal behavior.

Chapter 2 outlines the development of the state's constitution from a typical nineteenth century state constitution with a limited state government to a state constitution that reflects many of the principles espoused by the model state constitutions movement of the I950s and I960s. This chapter also examines the major amendments to the constitution and the influence of political cultures in pursuing these amendments.

Chapter 3 analyzes patterns of partisan strength across Kansas counties in terms of alignments that shape the political topography of the state's party system. This chapter assesses the validity of many of the traditional notions that describe these patterns and finds them in need of revision. In addition, this chapter examines the development of party organizations in terms of their ability to be candidate-centered organizations.

Chapter 4 analyzes the historical development of the state legislature from an institutional perspective and focuses on the influence of political cultures on institutional innovations designed to maintain the legislature's status as a citizen legislature. This chapter also analyzes the effects of the current political situation in the state legislature that was brought on by the factionalization of the majority Republican Party.

Chapter 5 reviews the evolution of the Kansas governorship and its transformation in the modern era. Selected Kansas governors are also examined in cultural context, that is, in terms of their contributions in building and sustaining cultural coalitions.

Chapter 6 discusses the development of interest group politics in the state. It focuses on the growing diversity of lobbying interests represented in the legislative process and the impact of this diversity on the way in which lobbyists interact with state legislators.

Chapter 7 examines the impact of the federal structure on politics and state and local governments in Kansas. The evolution of federalism in Kansas, both nation-state and state-local relations, is interpreted from the perspective of political cultures.

Chapter 8 tracks the profound transformation in state taxing, spending, and borrowing from a cultural perspective. Attention is given to major components of state taxation and expenditures and the recent ballooning of state debt.

Chapter 9 highlights major themes in Kansas politics and government. And finally, suggestions for further reading are provided after the notes section. 